\author{
A. Martynchuk ${ }^{1,2}$, V. Vasylyshyn ${ }^{2}, \mathrm{Wu}$ Lixiang $^{2,3}$, O. Martynchuk ${ }^{4}$ \\ ${ }^{1}$ Kharkiv National University of Radio Electronics, Kharkiv \\ ${ }^{2}$ Ivan Kozhedub Kharkiv National Air Force University, Kharkiv \\ ${ }^{3}$ Airforce engineering university, information and navigation college, China \\ ${ }^{4}$ National Technical University "Kharkiv Polytechnic Institute", Kharkiv
}

\title{
RESEARCH EFFICIENCY USE OF ORTHOGONAL DOUBLE POLARIZATION MIMO ANTENNAS IN DRONE COMMUNICATION
}

The article considers possible variants of application of various MIMO schemes for the communication with the drone or unmanned aerial vehicle. The model of multipath propagation of radio waves taking into account polarization parameters of antennas is given. The main focus is on the use of MIMO technology with polarizationorthogonal channels and channels with double polarization. The evaluation of the efficiency of using full polarization reception in comparison with MIMO channels of one polarization is given. Attention is paid to the presence of cross-polarization solution between the channels.

\section{Keywords: $M I M O, X P D$, dual polarization channels, Channel capacity}

\section{Introduction}

Formulation the problem. Drones are increasingly being used for military and civilian missions. The requirements for communication channels with drones have gradually evolved from ensuring the continuity and reliability of the control channel to a communication channel that requires large amounts of data. Increasing the channel capacity is an urgent task, the solution of which affects all the possibilities: increasing the power, improving antenna parameters, increasing the frequency band, mastering other frequency ranges, improving signal processing methods, as well as the development of multi-antenna technology. Wireless communication technology MIMO (Multiple Input and Output) is an important content of current research in the field of wireless communication. Its main idea is to use multiple antennas simultaneously at the transmitting and receiving sides of the communication system, making full use of the spatial degree of freedom of the wireless multipath channel. System bandwidth and transmission rates are being changed to more efficient use of the spectrum by increasing the complexity of the system. It is a powerful solution to meet the ever-increasing bandwidth requirements in rich multipath environments. It is also a key technology in modern wireless communications, as well as the main technology of the Wi-Fi 802.11, WiMAX 802.16, IEEE 802.20 and 5G standards. Increasing the throughput of the communication channel with the drone is possible due to the use of multi-polarized antennas on the transceivers. Therefore, the study of the communication channel with the drone, including the study of the properties of signal polarization during propagation, as well as the study of the polarization characteristics of MIMO antennas is also key.
The use of dual polarization channel technology can increase the throughput of a wireless communication system. An important element of research is channel modeling, which allows one to study the characteristics of signal fading. The technology of using MIMO antennas of dual polarization will allow full polarization reception of signals, which will reduce losses during propagation of radio waves in multipath conditions, can not only solve the problem of insufficient bandwidth, but also increase the reliability of the communication system as a whole.

Analysis of recent research and publications. In recent years, the use of MIMO technology with polarization-orthogonal channels has become a promising research area for next-generation mobile and fixed communication systems [1-3]. Increasing system capacity without increasing transmits power or bandwidth has made the MIMO system unique and efficient in transmitting data. However, the resulting bandwidth limitations due to final polarization decoupling are not well understood. In [4-13], attention is paid to polarization isolation, however, only in the presence of a $2 \times 2$ configuration using MIMO. Studies of the possibility of using an increase in the number of antennas of MIMO systems with polarization-orthogonal antennas have been insufficiently conducted. It is of interest to combine the obtained in the paper results with de-noising method [14] at the receiver side of MIMO system. The results of paper [15] shows that the application such method in the OFDM communication system permits to improve the system performance (for example, reduce the BER, improve the quality of channel estimation). Furthermore, the application of adaptive SSA method improves the performance of parameter estimation (fre- 
quency of the signal, direction of arrival and so on) [16] It can be useful in the problem of channel sounding.

The aim of the article is study of the possibility of increasing the capacity of the communication channel with an unmanned aerial vehicle using MIMO antennas with polarized orthogonal antennas.

\section{Statement of basic materials 1. MIMO technology}

In theory with multiple antennas, more than one antenna is usually used at both ends of transmit and receive signal. It is assumed that the number of transmitting antennas is $N$, and the number of receiving antennas is $M$. We write the transmitted signal as follows:

$$
S(t)=\left[\begin{array}{llll}
s_{1}(t) & s_{2}(t) & \ldots & s_{N}(t)
\end{array}\right]^{T} .
$$

The signal after fading in the receiving channel is shown as follows

$$
Y(t)=\left[\begin{array}{llll}
y_{1}(t) & y_{2}(t) & \ldots & y_{M}(t)
\end{array}\right]^{T} .
$$

Therefore, the channel between the transmitting and receiving sides can be expressed as a matrix

$$
H(\tau)=\sum_{l=1}^{L} H_{l} \delta\left(\tau-\tau_{l}\right)
$$

where $H(\tau) \in C^{M \times N}$, and has the form:

$$
H_{l}=\left[\begin{array}{cccc}
a_{11}^{l} & a_{12}^{l} & \ldots & a_{1 N}^{l} \\
a_{21}^{l} & a_{22}^{l} & \ldots & a_{2 N}^{l} \\
\ldots & \ldots & a_{m n}^{l} & \ldots \\
a_{M 1}^{l} & a_{M 2}^{l} & \ldots & a_{M N}^{l}
\end{array}\right]_{M \times N} .
$$

Assuming the time delay is $\tau_{l}$, to represent the channel transmission matrix, use $H_{l}$. Matrix element $a_{m n}^{l}$ is the propagation coefficient between a pair of receiving and transmitting antennas. $L-$ is the number of possible paths. We point out that, without taking into account the noise, the vector of the transmitted signal $S(t)$ and the vector of the received signal $Y(t)$ can be expressed through a convolution expression like so:

$$
Y(t)=\int H(\tau) S(t-\tau) d \tau .
$$

During the analysis, it is assumed that the coefficients of the channel transmission matrix are a complex Gaussian distribution with zero mean, and therefore the mode $a_{m n}^{l}$ obeys Rayleigh distribution. To model the process using the correlation method, some assumptions should be made.

First, the transmission coefficients of each path simultaneously have the same average power

$$
P_{l}=E\left\{\left|a_{m n}^{l}\right|^{2}\right\}, n \in[1,2, \ldots, N], m \in[1,2, \ldots, M] .
$$

Second, the correlation matrix of a MIMO system is often divided into two parts - the spatial correlation matrix and the polarization correlation matrix. For the convenience of the study, we assume the independence of the spatial and polarization correlation.

\section{Spatial correlation matrix}

MIMO works well in a multi-path environment; however, the spatial position of multiple antennas can cause severe fading between different channels. Spatial correlation coefficient $\rho_{12}$ between two antenna elements is an element spacing function, spectral characteristics (PAS - Power Angular Spectrum) and the radiation pattern of each element. It is assumed that the diagrams of the antenna elements are the same. This correlation coefficient can be calculated using the following formula.

$$
\rho_{12}=\frac{\int_{-\pi}^{\pi} e^{-2 j \pi \frac{d}{\lambda} \sin (\theta)} P A S(\theta) G(\theta) d(\theta)}{\int_{-\pi}^{\pi} P A S(\theta) G(\theta) d(\theta)},(6)
$$

where $d$ - distance between antenna elements, and $G(\theta)$ - antenna element radiation pattern.

Using the above formula, the spatial correlation matrix of the entire system can be computed, including the transmitter and receiver correlation matrices. For example, for a $2 \times 2$ MIMO system, the correlation matrix of the transmitting and receiving sides is expressed as:

$$
\begin{aligned}
R_{\text {T,space }} & =\left(\begin{array}{cc}
1 & \rho_{t 12} \\
* & 1 \\
\rho_{t 21} & 1
\end{array}\right), \\
R_{R, \text { space }} & =\left(\begin{array}{cc}
1 & r_{12} \\
* & 1 \\
r_{21} & 1
\end{array}\right) .
\end{aligned}
$$

The spatial correlation matrix of the system can be calculated using the Kronecker product:

$$
R_{S}=R_{R, \text { space }} \otimes R_{T, \text { space }} .
$$

Assuming that $\gamma-$ is the spatial correlation coefficient between adjacent antennas, $K=M=N$ - total number of receiving or transmitting antennas. Then the correlation matrix between the transmitting and receiving sides can be simplified and obtained by the following formula: 


$$
\begin{gathered}
R_{\text {T,space }}=R_{R, \text { space }}= \\
=\left(\begin{array}{cccc}
1 & e^{-1 \gamma} & \ldots & e^{-(K-1) \gamma} \\
e^{-1 \gamma} & 1 & \ldots & e^{-(K-2) \gamma} \\
\ldots & \ldots & \ldots & \ldots \\
e^{-(K-1) \gamma} & e^{-(K-2) \gamma} & \ldots & 1
\end{array}\right) .
\end{gathered}
$$

If two dual-polarized antennas are used in the transmitter and receiver to replace 4 single-polarized antennas, the system becomes a $2 \times 2$ dual-polarized MIMO system. Moreover $K=M / 2=N / 2$, the correlation matrix can be obtained by the following formula:

$$
=\left(\begin{array}{cccc}
R_{\text {T,space }}=R_{R, \text { space }} & \\
1 & e^{-2 \gamma} & \ldots & e^{-(K-1) 2 \gamma} \\
e^{-2 \gamma} & 1 & \ldots & e^{-(K-2) 2 \gamma} \\
\ldots & \ldots & \ldots & \ldots \\
e^{-(K-1) 2 \gamma} & e^{-(K-2) 2 \gamma} & \ldots & 1
\end{array}\right) .
$$

\section{Polarization correlation matrixes}

For MIMO systems, it may be necessary to place antennas at some distance to reduce their spatial correlation. However, the physical size of some wireless devices is getting smaller and smaller, and the distance between antennas is limited. In some cases, an alternative solution is required to achieve the low channel fading correlation required for MIMO operation. There is a method for reducing the spatial correlation between two antennas, which is to "cross-polarize" the antennas. In other words, the polarization of the two antennas is set orthogonal to each other. The spatial correlation between two short dipole antennas with vertical polarization $(0 / 0)$ is very high, while the correlation coefficient between antennas with orthogonal polarization (0/90) (one vertical and one horizontal) is much lower.

Using antennas with different polarizations in the transmitter and receiver can cause power imbalances and related imbalances between different MIMO channels. The degree of correlation between polarized antennas can be quantified using the cross-polarization factor, ratio or discrimination (XPR or XPD - Cross Polar Discrimination). XPR is the power ratio of a cross-polarized antenna pair and a co-polarized antenna pair $(v-v$ or $h-h)$. Let the antenna polarization matrix of the transmitter and receiver look like this:

$$
S=\left(\begin{array}{ll}
s_{v v} & s_{v h} \\
s_{h v} & s_{h h}
\end{array}\right) .
$$

In the formula, the subscript $v$ means vertical polarization, and $h$ means horizontal polarization. The first index represents the polarization at the transmitter and the second index represents the polarization at the receiver. If we assume that $\mathrm{XPD}=-8 \mathrm{~dB}$, then

$$
X P D=\frac{\left|s_{v h}\right|^{2}}{\left|s_{v v}\right|^{2}}=\frac{\left|s_{h v}\right|^{2}}{\left|s_{h h}\right|^{2}}=-8 d B \approx 0.016 .
$$

In principle, the cross-polarization coefficient depends on many factors, in particular, on the antenna design, observation angles in a spherical coordinate system, on the frequency range and bandwidth, on the signal spectrum, finally, when the antenna and signal parameters are not matched. However, such studies are beyond the scope of the tasks posed, therefore, we will restrict ourselves only to taking into account the polarization decoupling along the maximum of the antenna radiation. In general, for the entire channel, the XPD parameter depends on the type of polarization and propagation path, multipath conditions, the design of the transmitting and receiving antennas and their position in space.

Consider a linear polarized $2 \times 2$ MIMO system. Let the transmitting and receiving sides use dual polarized antennas. Let the polarization (orientation) angles of the transmitting antennas are $\alpha_{1}, \alpha_{2}$, and receiving antennas $\beta_{1}, \beta_{2}$. Then the polarization matrices will be:

$$
\begin{aligned}
& R_{T, p o l}=\left(\begin{array}{ll}
\cos \left(\alpha_{1}\right) & \cos \left(\alpha_{2}\right) \\
\sin \left(\alpha_{1}\right) & \sin \left(\alpha_{2}\right)
\end{array}\right), \\
& R_{R, p o l}=\left(\begin{array}{ll}
\cos \left(\beta_{1}\right) & \cos \left(\beta_{2}\right) \\
\sin \left(\beta_{1}\right) & \sin \left(\beta_{2}\right)
\end{array}\right) .
\end{aligned}
$$

The complete channel polarization matrix is defined as:

$$
P=R_{R, p o l} S R_{T, p o l} .
$$

The channel polarization matrix is defined as

$$
G=E\left\{\operatorname{vec}(P) \operatorname{vec}(P)^{\prime}\right\} \text {. }
$$

For certain polarization angles such as $+45 /-45 \mathrm{deg}$, 0/90deg и 0/0deg, and diagonal elements $G$ equal, which means there is no power imbalance between different channels. For any polarization angle, the diagonal elements are not equal and the polarization causes an undesirable power imbalance between channels. In order for the diagonal elements of the matrix to show the relative channel power, it must be normalized.

$$
G^{R}=\frac{K}{\sum_{i=1}^{K} G_{i, j}} G .
$$

This power normalization process is based on the following assumptions: for a MIMO system with transmit antennas $\mathrm{M}$ and receiving antennas $\mathrm{N}$ total channel power is $\mathrm{K}=\mathrm{MN}$. Correlation matrix $G^{R}$ reflects the imbalance of channels due to polarization, and its diagonal elements are related to the relative power in each channel. 
If two dual-polarized antennas are used in the transmitter and receiver to replace 4 single-polarized antennas, the system becomes a $2 \times 2$ dual-polarization MIMO system. The correlation matrix between the transmitter and receiver of this system is calculated using the following formula:

$$
\begin{aligned}
& R_{T}=R_{T, \text { space }} \otimes R_{T, \text { pol }}, \\
& R_{R}=R_{R, \text { space }} \otimes R_{R, \text { pol }} .
\end{aligned}
$$

Complete correlation matrix of the system:

$$
R_{M I M O}=R_{R} \otimes R_{T} .
$$

Having obtained (18), we form the corresponding matrix of the Cholesky decomposition or factorization. Having the correlation matrix $C$, it is possible to obtain a complex matrix of channel gains

$$
\operatorname{vec}\left(H_{l}\right)=\sqrt{P_{l}} C c_{l} .
$$

In the formula $\operatorname{vec}(\ldots)$ is the vectorization of the matrix, and $c_{l}-$ column vector $M N \times 1$, in which each element represents an independent small-scale fading, which basically represents the characteristics of the channel fading. Analysis shows that the temporal correlation of each subchannel and each path of each subchannel is independent of each other. Therefore, it is necessary to generate a total of $N \times M \times L$ independent fading. The effect of fading on a signal is multiplicative. Therefore, the attenuation manifested on each subchannel is equal to $C c_{l}$. We get a complex matrix $H_{l}$ channel gains with time delay $\tau_{l}, l=1, \ldots L$. We use $H_{l}$ in equation (3) to obtain the channel matrix $\mathrm{H}$.

\section{Modeling the drone communication channel}

When simulating a communication channel with a drone, it is necessary to take into account the phase difference caused by antenna spacing and methods of simulating the line-of-sight path.

Due to the mobility of the drone, the change in the angle of incidence, the angle between two adjacent antennas separated by the distance $\mathrm{d}$, the difference in the path of the rays will be equals to $d \sin (\phi)$. This will result in a phase difference between the antennas. The signal received at this time can be expressed as follows:

$$
\left.y(t)=W(\phi) \int H(\tau) s(t-\tau) d \tau\right),
$$

where $W(\phi)$ - diagonal matrix of directions when the average angle of arrival is $\phi$.

The diagonal matrix of directions is defined as follows:

$$
W(\phi)=\left(\begin{array}{cccc}
w_{1}(\phi) & 0 & \ldots & 0 \\
0 & w_{2}(\phi) & \ldots & 0 \\
\ldots & \ldots & \ldots & \ldots \\
0 & 0 & \ldots & w_{M}(\phi)
\end{array}\right)_{M x N}
$$

where $w_{m}(\phi)$ is the average phase shift relative to the first antenna when the average angle of incidence is $\phi$. Only when the antenna signals in the array are statistically independent of each other can the phase between the two antennas change randomly.

In the process of modeling a MIMO channel, the SISO frequency selective channel between each antenna pair has a line-of-sight path, so it is also necessary to take into account the phase change of the line-of-sight path in each channel. Therefore, the channel matrix at this time can be expressed in accordance with the equation (22), and $H_{L O S}$ represents the average line-ofsight power (LOS):

$$
H_{l}=\sqrt{K} \sqrt{P_{l}} H_{\text {LOS }}+\sqrt{P_{l}} H_{\text {Rayleigh }},
$$

$$
H_{L O S}(t)=e^{j 2 \pi f_{d} t}\left[\begin{array}{c}
1 \\
e^{j 2 \pi \frac{d_{R x}}{\lambda} \sin \left(A o A_{R x}\right)} \\
\ldots \\
e^{j 2 \pi \frac{d_{R x}}{\lambda}(M-1) \sin \left(A o A_{R x}\right)}
\end{array}\right] .
$$$$
\left[\begin{array}{c}
1 \\
e^{j 2 \pi \frac{d_{T x}}{\lambda} \sin \left(A o D_{T x}\right)} \\
\cdots \\
e^{j 2 \pi \frac{d_{T x}}{\lambda}(N-1) \sin \left(A o D_{T x}\right)}
\end{array}\right]
$$

where $f_{d}=(V / \lambda) \cos (\alpha)$, and the angle $\alpha$ there is an angle between the LOS component and the direction to the drone; $d_{R x}$ and $d_{T x}$ - distance between antennas of transmitter and receiver; $A o A_{R x}$ и $A o D_{T x}$ - angles of incidence of the receiving and transmitting channels.

\section{Simulation results}

Let's carry out only the simulation results of the flight scene. The sampling time of statistics is $0.1 \mathrm{sec}$ for observation. Vector of initial data of attenuation and delay $\mathrm{PDP}=[-3,-6,-9,-12,-15,-18(\mathrm{~dB}) ; 0,010,020,03$ $0,040,050,06(\mu \mathrm{s})]$, sampling rate $f_{s}=1 \times 103 \mathrm{~Hz}$, total 100 sampling points. The following simulation results were obtained. The figures below show the results of estimating the channel capacity and spatial correlation for various variants of the model. The average value of the throughput is shown in red. For the MIMO $4 \times 4(4 \mathrm{v}$ $\times 4 \mathrm{v}$ ) models with four transmitting and receiving antennas of vertical polarization, we observe a change in the specific bandwidth from $18 \mathrm{bps} / \mathrm{Hz}$ to $25 \mathrm{bps} / \mathrm{Hz}$ at an observation interval of $0.1 \mathrm{~s}$ (Fig. 1, left graph). The average value of the specific bandwidth is about $22 \mathrm{bps} / \mathrm{Hz}$. The value of the spatial correlation at the zero level is about half the wavelength (Fig. 1, right graph). 

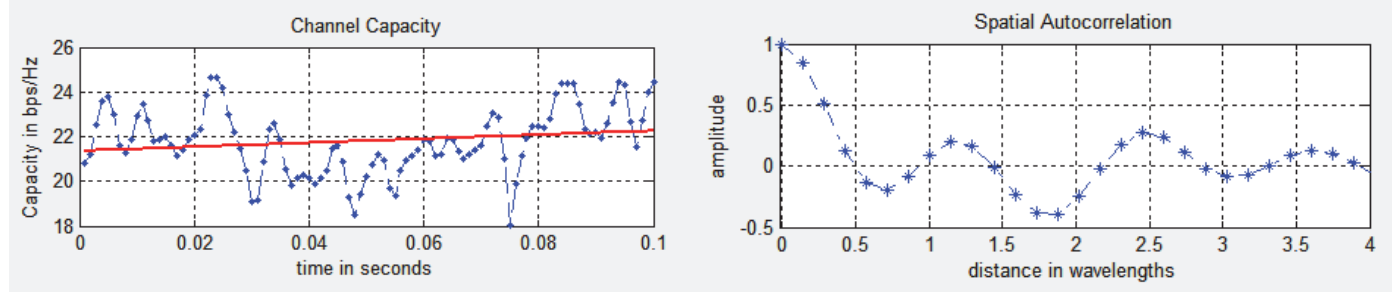

Fig. 1. Model MIMO $4 \times 4$, polarization vertical $(4 v \times 4 v)$
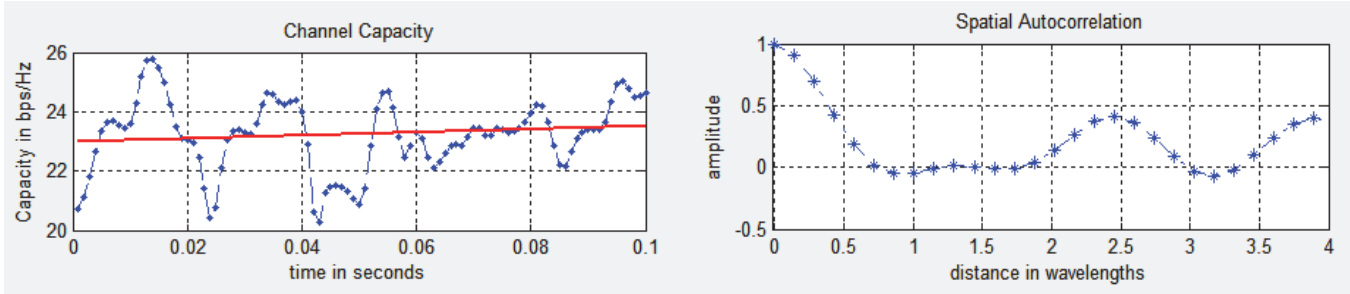

Fig. 2. MIMO model $4 \times 4$, dual polarization $(2 \mathrm{v}-2 \mathrm{~h} \times 2 \mathrm{v}-2 \mathrm{~h})$

Dual Polarization $4 \times 4$ MIMO Model $(2 \mathrm{v}-2 \mathrm{~h} \times 2 \mathrm{v}$ 2h) shows a decrease in fluctuations in the specific bandwidth over the observation interval (increase in the correlation time) and a slight increase in the average value - up to $23.5 \mathrm{bps} / \mathrm{Hz}$ (Fig. 2, left graph). A decrease in spatial fluctuations is also observed with an increase in the distance between antennas (Fig. 2, right graph). In this case, the value of the spatial correlation at the zero level slightly increases up to 0.7 of the wavelength.

$4 \times 4$ MIMO simulation results with orthogonal polarization, or cross-dual polarization, antennas are shown in Fig. 3 and 4 at different polarization decoupling. Note that the use of 4 antennas of orthogonal polarization also leads to a further decrease in specific bandwidth fluctuations (further increase in the correlation time) in the observation interval (from 28 to $35 \mathrm{bps} / \mathrm{Hz}$ ) and to an increase in the average value - up to $31 \mathrm{bps} / \mathrm{Hz}$. (Fig. 3, left graph). In this case, the value of the spatial correlation at the zero level decreases to approximately 0.26 of the wavelength (Fig. 3, right graph).
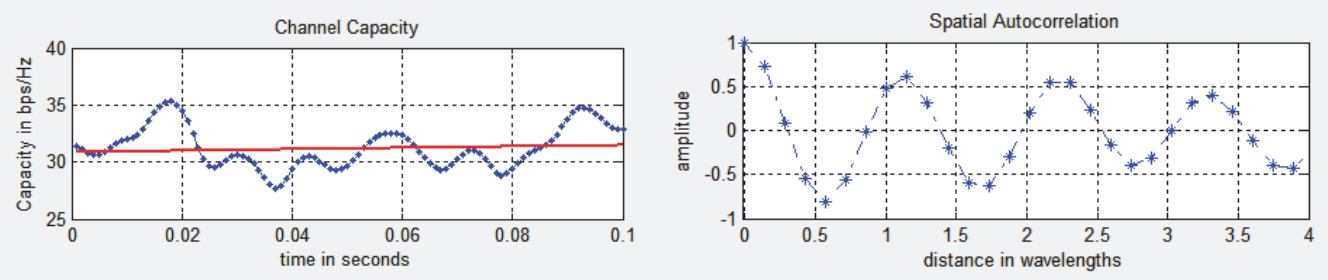

Fig. 3. MIMO model $4 \times 4$, cross-dual polarization, XPD $=10 \mathrm{~dB}(4 \mathrm{v}-4 \mathrm{~h} \times 4 \mathrm{v}-4 \mathrm{~h})$

Improvement in polarization isolation leads to some improvement in specific bandwidth - an average
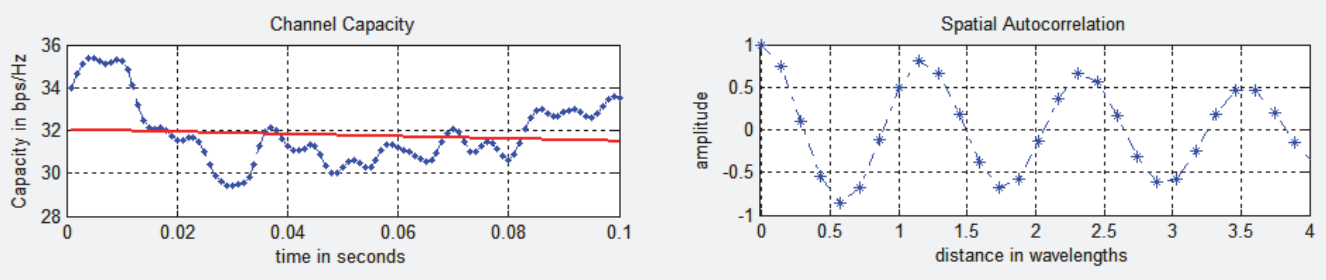

Fig. 4. MIMO model $4 \times 4$, cross-dual polarization XPD $=15 \mathrm{~dB}(4 \mathrm{v}-4 \mathrm{~h} \times 4 \mathrm{v}-4 \mathrm{~h})$

Note that the use of 4 antennas of orthogonal polarization with improved polarization isolation up to $\mathrm{XPD}=15 \mathrm{~dB}$ also leads to a decrease in specific bandwidth fluctuations (further increase in the correlation time) in the observation interval (from 29.5 to 35.5 $\mathrm{bps} / \mathrm{Hz}$ ). At the same time, the value of spatial correlation at the zero level does not change significantly (Fig. 4 , right graph). The results of the comparative analysis are summarized in Table 1. 
Results of a comparative analysis of the effectiveness of various models of MIMO schemes

\begin{tabular}{|c|c|c|}
\hline MIMO model $4 \times 4$ & $\begin{array}{c}\text { Average value of specific } \\
\text { bandwidth, bps/Hz }\end{array}$ & $\begin{array}{c}\text { Zero level spatial correlation, } \\
\text { wavelength }\end{array}$ \\
\hline polarization vertical $(4 \mathrm{v} \times 4 \mathrm{v})$ & 22 & 0,5 \\
\hline dual polarization $(2 \mathrm{v}-2 \mathrm{~h} \times 2 \mathrm{v}-2 \mathrm{~h})$ & 23.5 & 0,7 \\
\hline cross-dual polarization, $\mathrm{XPD}=10 \mathrm{~dB}$ & 31 & 0,26 \\
\hline cross-dual polarization $\mathrm{XPD}=15 \mathrm{~dB}$ & 32 & 0,26 \\
\hline
\end{tabular}

So, thanks to the use of full polarization reception due to antennas of dual orthogonal polarization, it turned out to be possible to improve the average value of the specific capacity of the communication channel with the drone and reduce the value of spatial correlation at the zero level, which is important in the design of promising communication channels and the design of antennas.

\section{Conclusion}

Comparing the results of the study of various schemes of the MIMO model, one can draw conclusions about the effect of the type of antenna polarization on the channel capacity. It is important to take into account the depolarization of the signal during propagation, when full polarization reception will significantly reduce the loss due to the mismatch of the polarization of the incident wave and the receiving antenna. On the other hand, the use of dual polarized antennas can reduce the spatial correlation between antennas, which will reduce the size of the antenna itself. Finally, the use of antennas with dual orthogonal polarization at the receiving and transmitting positions will significantly reduce the polarization loss and improve the throughput. Antenna decoupling affects throughput, necessitating further research into antenna designs with improved polarization decoupling.

\section{References}

1. Foschini, G.J. (1996), Layered space-time architecture for wireless communications in a fading environment when using multi-element antennas, Bell Labs Technical Journal, pp. 41-59.

2. Murch, R.D. and Letaief, K.B. (2002), Antenna systems for broadband wireless access, IEEE Commun. Mag., Vol. 49, No. 1, pp. 70-83.

3. Wong, K., Cheng, R.S., Letaief, K.B. and Murch, R.D. (2001), Adaptive antennas at the mobile and base stations in an OFDM/TDM A systems, IEEE Transactions on Communications, Vol. 49, No. 1, pp. 195-206.

4. Martynchuk, A.A. Ikram Kadir and Zubrytskyi, H.M. (2012), Increasing radio channel capacity method of MIMO system using orthogonal-polarization antenna technique, Control, Navigation and Communication Systems, No. 3 (23), pp. 241-247.

5. Martynchuk, A.A., Ikram Kadir and Zubrytskyi, H.M. (2013), Characteristic investigation of orthogonal-polarized antennae on the radio channel capacity, XII international conference "The experience of designing and application of CAD systems in microelectronics (CADSM 2013)", Lviv, pp. 242-246.

6. Martynchuk, A.A., Nazmutdinov, A.A., Skorohod, A.N. and Assamoi Regis Arnaud (2013), Mathematical model of the signal in the Wi-Fi channel with orthogonal polarization MIMO antennas, Problemy ynfokommunykacyj. Nauka y tekhnologhyy (RIS S\&T-2013): Sbornyk nauchnykh trudov pervoj mezhdunarodnoj nauchno-praktycheskoj konferencyy, Ministry of Education and Science of Ukraine, Kharkiv National University of Radio Electronics, pp. 201-205.

7. Martynchuk, A.A., Nazmutdinov, A.A. and Skorohod, A.N. (2014), Influence cross-polarization decoupling on Wi-Fi MIMO system capacity, First International Scientific-Practical Conference Problems of Infocommunications Science and Technology. PICS\&T 2014, pp. 127-129.

8. Popovskyy, V., Loshakov, V. and Marchuk, A. (2016), Analysis of possibilities for improving the characteristics of tropospheric communication station, Proceedings of International Scientific-Practical Conference Problems of Infocommunications Science and Technology (PICS\&T-2014), Kharkiv, pp. 195-198.

9. Martynchuk, A.A., Loshakov, V.A. and Oliver, L.M. (2015), Development of a trans-horizon communication system based on dual polarization MIMO architecture, Electromagnetic Compatibility Issues for Advanced Wireless Communication Networks (EMC-2015), Kharkiv National University of Radio Electronics, Kharkiv.

10. Popovskii, V., Loshakov, V., Filipenko, O., Martynchuk, O. and Drif, A. (2015), Results of development tropospheric communications system, 2015 Second International Scientific Practical Conference "Problems of Infocommunications. Science and Technology", ANPRE, Kharkiv.

11. Loshakov, V., Martynchuk, A., Nazmutdinov, A., Skorohod, A. and Drif, A. (2016), Research the efficiency and feasibility of circular polarization in the tropospheric radio link, 2016 Third International Scientific-Practical Conference "Problems of Infocommunications. Science and Technology”. PIC S\&T 2016. Kharkiv National University of Radio Electronics, Kharkiv, pp. 99-102.

12. Martynchuk, A., Nazmutdynov, A., Skorokhod, A., Florov, A. and Bortnovsky, S. (2017), Spatial polarization suppression of active interference in a tropospheric polarization-orthogonal communication channel, 2017 IEEE 4th International Scientific-Practical Conference "Problems of Infocommunications. Science and Technology". PIC S\&T 2017. Kharkiv National University of Radio Electronics, Kharkiv, pp. 589-591.

13. Martynchuk, A., Zubritskyi, H., Xuan, Li and Martynchuk, O. (2020), Some limitations of evaluating dual-polarized MIMO channel capacity, Information Processing Systems, No. 2(161), pp. 16-21. https://doi.org/10.30748/soi.2020.161.02. 
14. Vasylyshyn, V. (2021), Adaptive complex singular spectrum analysis with application to modern superresolution methods, Data-centric business and applications. Lecture notes on data engineering and communications technologies, Vol 48, Springer, Cham, pp. 35-54.

15. Vasylyshyn, V. (2020), Channel estimation method for OFDM communication system using adaptive singular spectrum analysis, 2020 IEEE 40th International conference on electronics and nanotechnology (ELNANO), Kyiv, Ukraine. https://doi.org/10.1109/ELNANO50318.2020.9088787.

16. Vasylyshyn, V. (2019), Estimation of signal parameters using SSA and Unitary Root-Music, Proc. of 2019 IEEE International Scientific-Practical Conference Problems of Infocommunication, Science and Technology (PIC S\&T), Kharkiv, pp. 789-793.

\section{Список літератури}

1. Foschini G.J. Layered space-time architecture for wireless communications in a fading environment when useing multielement antennas. Bell Labs Technical Journal. Aug. 1996. P. 41-59.

2. Murch R.D., Letaief K.B. Antenna systems for broadband wireless access. IEEE Commun. Mag. 2002. Vol. 49. No. 1. P. 70-83.

3. Wong K., Cheng R.S., Letaief K.B., Murch, R.D. Adaptive antennas at the mobile and base stations in an OFDM/TDM A systems. IEEE Transactions on Communications. Vol. 49. No. 1. P. 195-206.

4. Martynchuk A.A., Kadir Ikram, Zubrytskyi H.M. Increasing radio channel capacity method of MIMO system using orthogonal-polarization antenna technique. Системи управління, навігащії та зв'язку. 2012. Вип. 3 (23). С. 241-247.

5. Martynchuk A.A., Ikram Kadir, Zubritsky G.N. Characteristic investigation of orthogonal-polarized antennae on the radio channel capacity. Досвід розробки та застосування приладо-технологічних САПР в мікроелектроніці: Матеріали XII Міжнародної науково-технічної конференції CADSM 2013. Львів: Видавництво Національного університету "Львівська політехніка", 2013. С. 242-246.

6. Martynchuk A.A., Nazmutdinov A.A., Skorohod A.N., Assamoi Regis Arnaud. Mathematical model of the signal in the Wi-Fi channel with orthogonal polarization MIMO antennas. Проблемы инфокоммуникаций. Наука и технологии (PIC S\&T2013): Сборник научных трудов первой международной научно-практической конферениии. Харьков 9-11 октября 2013 г. Министерство образования и науки Украины, Харьковский национальный университет радиоэлектроники. Харьков : ХНУРЭ, 2013. С. 201-205.

7. Martynchuk A.A., Nazmutdinov A.A., Skorohod A.N. Influence cross-polarization decoupling on Wi-Fi MIMO system capacity, 2014 First International Scientific-Practical Conference Problems of Infocommunications Science and Technology. PICS\&T 2014. Харьков : АНПРЭ, ХНУРЭ, 2014. С. 127-129.

8. Popovskyy V., Loshakov V., Marchuk A. Analysis of possibilities for improving the characteristics of tropospheric communicationstation. Proceedings of International Scientific-Practical Conference Problems of Infocommunications Science and Technology (PICS\&T-2014). Kharkiv, 2016. pp. 195-198.

9. Martynchuk A.A., Loshakov V.A., Oliver L.M. Development of a trans-horizon communication system based on dual polarization MIMO architecture. Проблемы электромагнитной совместимости перспективных беспроводных сетей связи (EMC-2015). Харьков : ХНУРЭ, 2015.

10. Popovskii V., Loshakov V., Filipenko O., Martynchuk O., Drif A. Results of development tropospheric communications system. 2015 Second International Scientific Practical Conference "Problems of Infocommunications. Science and Technology". Харків : АНПРЕ, 2015.

11. Loshakov V., Martynchuk A., Nazmutdinov A., Skorohod A., Drif A. Research the efficiency and feasibility of circular polarization in the tropospheric radio link. 2016 Third International Scientific-Practical Conference "Problems of Infocommunications. Science and Technology”. PIC S\&T 2016. Харків : ХНУРE, 2016. C. 99-102.

12. Martynchuk A., Nazmutdynov A., Skorokhod A., Florov A., Bortnovsky S. Spatial polarization suppression of active interference in a tropospheric polarization-orthogonal communication channel. 2017 IEEE 4th International Scientific-Practical Conference "Problems of Infocommunications. Science and Technology". PIC S\&T 2017. Харків : ХНУРE, 2017. С. 589-591.

13. Martynchuk A., Zubritskyi H., Xuan Li, Martynchuk O. Some limitations of evaluating dual-polarized MIMO channel capacity. Системи обробки інформації. 2020. №. 2(161). C. 16-21. https://doi.org/10.30748/soi.2020.161.02.

14. Vasylyshyn V. Adaptive complex singular spectrum analysis with application to modern superresolution methods. Data-centric business and applications. Lecture notes on data engineering and communications technologies. Vol. 48 / T. Radivilova, D. Ageyev, N. Kryvinska, Eds. Springer, Cham, 2021. P. 35-54.

15. Vasylyshyn V. Channel estimation method for OFDM communication system using adaptive singular spectrum analysis. 2020 IEEE 40th International conference on electronics and nanotechnology (ELNANO). Kyiv : 2020. https://doi.org/10.1109/ELNANO50318.2020.9088787.

16. Vasylyshyn V. Estimation of signal parameters using SSA and Unitary Root-Music. Proc. of 2019 IEEE International Scientific-Practical Conference Problems of Infocommunication, Science and Technology (PIC S\&T). Kharkiv, 2019. pp. 789-793.

\section{Відомості про авторів:}

Мартинчук Олександр Олександрович
кандидат технічних наук, доцент
доцент кафедри Харківського національного
університету радіоелектроніки,
Харків, Україна
https://orcid.org/0000-0001-9729-4401

\section{Information about the authors:}

\section{Alexander Martynchuk}

$\mathrm{PhD}$ Associate Professor

Senior Lecturer of Department

of Kharkiv National University of Radio Electronics,

Kharkiv, Ukraine

https://orcid.org/0000-0001-9729-4401 
Василишин Володимир Іванович

доктор технічних наук професор начальник кафедри

Харківського національного університету

Повітряних Сил ім. І. Кожедуба,

Харків, Україна;

https://orcid.org/0000-0002-5461-0125

\section{У Лісян}

магістрант Харківського національного

університету Повітряних Сил

ім. І. Кожедуба,

Харків, Україна

Університет Повітряних Сил,

Сіань, Китай

https://orcid.org/0000-0002-4704-5770

\author{
Мартинчук Оксана Олексіївна \\ доцент кафедри \\ Національного технічного університету \\ "Харківський політехнічний інститут", \\ Харків, Україна \\ https://orcid.org/0000-0002-4955-5635
}

Volodymyr Vasylyshyn

Doctor of Technical Sciences Professor

Head of Department of Ivan Kozhedub

Kharkiv National Air Force University,

Kharkiv, Ukraine

https://orcid.org/0000-0002-5461-0125

\author{
Wu Lixiang \\ Graduate Student \\ of Ivan Kozhedub Kharkiv National \\ Air Force University, \\ Kharkiv, Ukraine \\ Airforce Engineering University, \\ Xi'an, China \\ https://orcid.org/0000-0002-4704-5770
}

\author{
Oksana Martynchuk \\ Senior Lecturer of Department \\ of National Technical Universit \\ "Kharkiv Polytechnic Institute", \\ Kharkiv, Ukraine \\ https://orcid.org/0000-0002-4955-5635
}

\section{ДОСЛІДЖЕННЯ ЕФЕКТИВНІСТІ ВИКОРИСТАННЯ ОРТОГОНАЛЬНОЇ ПОДВІЙНОЇ ПОЛЯРИЗАЦІЇ MIMО АНТЕН В КАНАЛАХ ЗВ'ЯЗКУ 3 ДРОНОМ}

О.О. Мартинчук, В.І. Василишин, У Лісянь, О.О.Мартинчук

У статті розглядаються можливі варіанти застосування різних схем МІМО для організаиії зв'язку з безпілотним літальним апаратом. Наводиться модель багатопроменевого поширення радіохвиль з урахуванням поляризачійних параметрів антен. Основна увага приділяється використанню технології МІМО з поляризаційно-ортогональними каналами і каналами з подвійною поляризачією. Наводиться оиінка ефективності використання повного поляризаиійного прийому в порівнянні з каналами МІМО однієї поляризаџії. Приділяється увага наявності крос-поляризаиійної розв'язки між каналами. Зазначене співвідношення визначається в основному конструктивними особливостями антен. Пропонується обирати антени з мінімально можливими значеннями коефіцієнта крос-поляризачійної розв'язки для забезпечення підвищення пропускної здатності.

Предметом дослідження являються МІМО-технології з поляризачійно-ортогональними каналами для організаиії зв'язку з безпілотним літальним апаратом. Забезпечення впевненого зв'язку з безпілотним літальним апаратом в умовах багатопроменевого розповсюдження радіохвиль та з урахуванням поляризаиійних властивостей сигналів являється важливим завданням. Дослідження можливості використання збільшення кількості антен систем МІМО з поляризаційно-ортогональними антенами, щзо забезпечують повний поляризачійний прийом, проведено недостатньо, тому $i$ тема роботи, що пов'язана з дослідженням покращення пропускної здатності МІМО каналу зв'язку з безпілотним літальним апаратом з антенами подвійної поляризації, є актуальною.

Метою статті є дослідження можливості збільшення пропускної здатності каналу зв'язку з безпілотним літальним апаратом з використанням антен МІМО з поляризаційними ортогональними антенами.

Результати досліджень свідчать про можливості збільшення пропускної здатності каналу зв'язку з безпілотним літальним апаратом з використанням антен МІМО з поляризаційними ортогональними антенами.

Область застосування результатів дослідження - проектування каналів зв'язку з безпілотним літальним апаратом з використанням технології МІМО з антенами подвійної поляризації та з врахуванням паразитного впливу кросполяризачійного сигналу антен подвійної поляризаџіï.

Ключові слова: МIMO, ХPD, подвійні поляризачійні канали, ємність каналу.

\section{ИССЛЕДОВАНИЕ ЭФФЕКТИВНОСТИ ИСПОЛЬЗОВАНИЯ ОРТОГОНАЛЬНОЙ ДВОЙНОЙ ПОЛЯРИЗАЦИИ MIMО АНТЕНН В КАНАЛАХ СВЯЗИ С ДРОНОМ}

А.А. Мартынчук, В.І. Василишин, У Лисянь, О.О.Мартинчук

В этой статье рассматриваются возможные варианты применения различных схем МІМО для организации связи с беспилотным летательным аппаратом. Приводится модель многолучевого распространения радиоволн с учетом поляризачионных параметров антенн. Основное внимание уделяется использованию технологии МІМО с поляризационно-ортогональныли каналами и каналам с двойной поляризацией. Приводится оиенка эффективности использования полного поляризационного приема в сравнении с каналами МІМО одной поляризачии. Уделяется внимание наличию кросс-поляризационной развязки между каналами. Указанное соотношение определяется в основном конструктивными особенностями антенн. Предлагается выбирать антенны с минимально возможными значениями коэффициента кросс-поляризационной развязки для обеспечения повыщения пропускной способности.

Ключевые слова: МIMO, ХРD, поляризационно-ортогональные канальl, емкость канала. 